\title{
TLR7 Agonist ANA773 Tosylate
}

National Cancer Institute

\section{Source}

National Cancer Institute. TLR7 Agonist ANA773 Tosylate. NCI Thesaurus. Code C95699.

The tosylate salt form of ANA773, a Toll-Like Receptor 7 (TLR7) agonist prodrug with potential immunostimulating activity. Upon oral administration, ANA773 is metabolized into its active form that binds to and activates TLR7, thereby stimulating dendritic cells (DCs) and enhancing natural killer cell (NK) cytotoxicity. This activation results in the production of proinflammatory cytokines, including interferon alpha, and enhanced antibody-dependent cellular cytotoxicity (ADCC). TLR7 is a member of the TLR family, which plays a fundamental role in pathogen recognition and activation of innate immunity. 